IZA DP No. 8731

Household Shocks and Education Investment in Madagascar

Peter J. Glick

David E. Sahn

Thomas F. Walker

December 2014 


\title{
Household Shocks and Education Investment in Madagascar
}

\author{
Peter J. Glick \\ RAND Corporation \\ David E. Sahn \\ Cornell University, \\ IZA and CERDI
}

\section{Thomas F. Walker}

World Bank

\section{Discussion Paper No. 8731 \\ December 2014}

\author{
IZA \\ P.O. Box 7240 \\ 53072 Bonn \\ Germany \\ Phone: +49-228-3894-0 \\ Fax: +49-228-3894-180 \\ E-mail: iza@iza.org
}

\begin{abstract}
Any opinions expressed here are those of the author(s) and not those of IZA. Research published in this series may include views on policy, but the institute itself takes no institutional policy positions. The IZA research network is committed to the IZA Guiding Principles of Research Integrity.

The Institute for the Study of Labor (IZA) in Bonn is a local and virtual international research center and a place of communication between science, politics and business. IZA is an independent nonprofit organization supported by Deutsche Post Foundation. The center is associated with the University of Bonn and offers a stimulating research environment through its international network, workshops and conferences, data service, project support, research visits and doctoral program. IZA engages in (i) original and internationally competitive research in all fields of labor economics, (ii) development of policy concepts, and (iii) dissemination of research results and concepts to the interested public.
\end{abstract}

IZA Discussion Papers often represent preliminary work and are circulated to encourage discussion. Citation of such a paper should account for its provisional character. A revised version may be available directly from the author. 
IZA Discussion Paper No. 8731

December 2014

\section{ABSTRACT \\ Household Shocks and Education Investment in Madagascar $^{1}$}

This paper measured the extent to which households in Madagascar adjust children's school attendance in order to cope with exogenous shocks to household income, assets and labour supply. Our analysis was based on a unique data set with 10 years of recall data on school attendance and household shocks. We found that the probability of a child dropping out of school increased significantly when the household experienced an illness, death or asset shock. We proposed a test to distinguish whether the impact of shocks on school attendance could be attributed to credit constraints, labour market rigidities, or a combination of the two. The results of the test suggested that credit constraints, rather than labour market rigidities, explain the inability of households in Madagascar to keep their children in school during times of economic distress.

JEL Classification: $\quad$ I25, J22, D13, E24

Keywords: education, development, household shocks, time allocation, labor supply, Madagascar

Corresponding author:

David E. Sahn

Cornell University

B16 MVR Hall

Ithaca, New York 14853

USA

E-mail: David.Sahn@cornell.edu

\footnotetext{
${ }^{1}$ We would like to acknowledge the useful comments of George Jakubson.
} 


\section{Introduction}

In recent years, Madagascar has made considerable progress in raising its net primary school enrolment rate, from $67 \%$ in 2001-2002 to $98 \%$ in 2004-2005 (World Bank, 2008). This is often attributed to the decision to eliminate school fees for public primary education in 2002, following a prolonged political crisis. The provision of free school supplies (a book bag, a textbook and a kit containing pencils and other items) to all primary school children also is considered to have played an important role. Nonetheless, as of 2011, primary completion rates remained around 70\%, and dropout rates around 60\% (World Bank, 2014). Delayed enrolment is also a concern, with nearly a third of children enrolling in school after their sixth birthday, and over $8 \%$ after age nine.

From a policy perspective, it is important to understand the factors preventing children in Madagascar from progressing further in their education. This is especially crucial, given that two-thirds of the population in Madagascar live below the poverty line, and education is important in determining success in the labour market, both in terms of finding a job in the small but expanding formal labour market and in terms of wages received. As in much of Africa, unemployment is low, with $88 \%$ of adults working, although many are working poor, especially those in agriculture where returns are the lowest. In rural areas, where $80 \%$ of workers reside, increases in education are associated with higher hourly earnings, even among agricultural workers (Hoftijzer and Paci, 2008; Glick, 1999). It is in this context that we explored whether unanticipated health and economic shocks caused children to drop out of school or delay enrolment, thereby compromising their future welfare and employment prospects. Understanding the impact of shocks on education decisions - and the channels of this impact - could help in designing safety nets and other policies to insulate investments in education from such shocks.

There have been a few studies that attempt to measure the impact of unanticipated shocks on education investment; the literature is discussed in detail in Section II. Our paper built on this literature by employing a discrete hazard model to test the response of school attendance in Madagascar to various types of idiosyncratic household shocks. This model captured the trade-off in allocation of children's time between labour, leisure and schooling, which in the absence of complete markets is inseparable from household resources (Becker, 1965; Jacoby and Skoufias, 1997). ${ }^{2}$ A novelty of our study was the unusually detailed data set used, which came from a nationwide survey of schooling and educational attainment in Madagascar. Ten years of recall data were collected on various idiosyncratic shocks, mostly events expected to cause economic stress. These included illness and death of the household head and spouse; transitions into unemployment; unanticipated loss of crops, land and livestock; and lower-than-expected business income. We found strong evidence that such shocks result in higher rates of dropout and lower rates of enrolment. We also examined the impacts on enrolment and dropout of access to secondary schools, local primary school quality and a government-sponsored health program, Secaline, which provides iron and folate supplementation, deworming and other types of nutrition to children enrolled in primary school.

Another innovation of this paper was that we tested how credit market and labour market rigidities differentially moderate the effects of shocks on schooling decisions.

\footnotetext{
2 'Complete markets' here included not only access to formal savings and credit instruments, but also informal arrangements that would fully insure the household against unanticipated shocks to income and assets (see, e.g., Townsend, 1994; Udry, 1994).
} 
Previous studies have illustrated how, in the presence of incomplete markets, parents may be compelled to withdraw their children from school in response to shocks, because they cannot borrow sufficiently to both sustain household consumption and continue investing in their children's human capital. However, we proposed that such a response might also reflect labour market constraints: the family may be unable to obtain (or may incur significant costs to obtain) replacement labour for family enterprises if the household's labour supply is diminished as the result of a shock. ${ }^{3}$ Based on the premise that there is gender differentiation in household based tasks, we developed a partial test between the two effects. Our results supported the conclusion that credit constraints, rather than labour market rigidities, explain the transmission of economic shocks to schooling decisions.

The paper proceeds as follows: In Section II we look at the previous literature on household shocks and schooling decisions. We then develop a simple, empirical test to partially distinguish credit market imperfections from labour market imperfections in Section III. In Section IV, we translate this into an econometric framework for the subsequent analysis, using a unique data set described in Section V. Section VI discusses the results; and Section VII concludes.

\section{Shocks and schooling decisions}

Where financial markets are imperfect or incomplete, households employ a variety of methods to cope with unanticipated negative health and economic shocks (see, for example, Fafchamps (2003)). One method is to reallocate the time of household members, for instance, by taking children out of school to work in the household or elsewhere. This short-run coping mechanism can have long-run implications for children's human capital accumulation and lifetime earnings capacity. Children are less likely to drop out in response to household shocks when financial markets are complete, in which case optimal levels of human capital investment are chosen based on market rates of return (Brown and Park, 2002; Ersado, 2005; Jacoby and Skoufias, 1997; Fuller and Liang, 1999).

Shocks might also delay the enrolment of children not already in school. Although it is unlikely that very young children would be required to work in response to a negative shock, such an event may diminish the household's capacity to afford the costs associated with schooling. Aside from school fees, parents may have to pay for uniforms, books and other expenses. Thus, during periods of economic stress, parents may choose to delay the enrolment of their children.

Studies from a range of developing countries have found evidence that school attendance falls and child labour increases in response to negative shocks. Perhaps, the most well-known household-level study was conducted by Jacoby and Skoufias (1997), who found that children in India missed days at school to help out at home. Jensen (2000) used various indicators to establish that children in Côte d'Ivoire, whose households suffered adverse rainfall shocks, were less likely to attend school. Sawada and Lokshin (1999) found similar evidence for communities in Pakistan, where children left school in response to transitory income shocks. Studying Tanzanian households, Beegle et al. (2006) found that unexpected crop losses led to an increase in child labour, but also observed that this effect was smaller in households that had assets with which to absorb the shock. Finally, Duryea et al. (2007) used

\footnotetext{
${ }^{3}$ This need not mean paid workers; in some situations, households may be able to draw on extended family or friends for temporary assistance.
} 
data from Brazil's monthly employment survey to establish that employment rates were higher and grade advancement rates lower for children whose fathers were unemployed.

The death of a parent can adversely affect children through a range of mechanisms, including the loss of financial resources, emotional distress and reduced parental investment in child human capital. Evidence from Indonesia and Mexico (Gertler et al., 2003) showed that a child whose parent suffered death or disability was more likely to drop out and less likely to enrol in school. This was the case even when the authors controlled for changes in household economic status. Suryadarma et al. (2009) found a similar result in the case of orphans in Indonesia, using a panel data set to show that parental death adversely affected school enrolment. Likewise, Gertler et al. (2004) reported that a child whose parent had recently died was, on average, twice as likely to drop out as a child with living parents. This effect is highest for youth at the transitions between primary and junior secondary school, and between junior secondary and senior secondary school. Evidence from South Africa (Operario et al., 2008) also pointed to the adverse effects of orphanhood (often a result of HIV/AIDS) on educational outcomes of girls, despite the fact that school attendance is compulsory through age 16. Interestingly, this effect applied to both cases where the mother or father (but not both) died. Similarly, in Malawi-another country ravaged by HIV/AIDSindications are that orphans have lower school enrolment, and that this effect is increased at higher grade levels. Case et al. (2004) similarly found that orphans in 10 sub-Saharan African countries were less likely than non-orphaned children to be enrolled in school; unlike in Operario et al., this applied to both boys and girls. Beegle et al. (2007) showed that the education of children who are maternal orphans in Tanzania was adversely affected, but the results for the death of the father were not consequential. One review paper that indicated the evidence on the impact of orphanhood was mixed was conducted by Burke (2006). Lloyd and Blanc's (1996) early empirical study from seven sub-Saharan African countries, ${ }^{4}$ likewise, did not find any difference in the education outcomes of orphans. Overall, however, this literature is often problematic in terms of proving causation, especially for those that have relied on cross-sectional surveys. ${ }^{5}$ And even if causation was strongly suggested, it was often difficult to distinguish between the various plausible mechanisms at play, including stigma, financial and psychological factors, and the disruption of forced migration.

\section{Theoretical model}

In Glick et al. (2011), we developed a discrete-choice model of household investment in children's education based on the framework of Jacoby and Skoufias (1997). The model described the process by which economic and health shocks could cause children to drop out of school or delay enrolment, and was used in this paper to guide the specification of a hazard model with which we estimated the impact of shocks on children's school attendance decisions. We also derived several testable predictions about the impact of credit and labour market rigidities on the propensity of children to drop out of school in order to supplement family labour. The trade-off between school attendance and work could, in theory, lead to outcomes of partial attendance; however, beyond a point, absenteeism will inevitably culminate in dropout. In this paper, we focused on the discrete decision for a child to drop out of school permanently - the extreme consequence of shocks on human capital accumulation.

\footnotetext{
${ }^{4}$ These were Kenya, Zambia, Tanzania, Cameroon, Namibia, Malawi and Niger.

${ }^{5}$ For example, there may be a correlation between who gets AIDS and income levels, both of which may independently affect schooling outcomes for children.
} 
The logic behind the standard education investment model is that each child will attend school as long as the marginal benefit of schooling (in terms of discounted future income and any consumption value) exceeds the present opportunity cost (foregone earnings and school attendance costs). Jacoby and Skoufias (1997) showed that if households had access to complete credit markets, they could borrow to offset transitory income or consumption shocks, leaving the schooling attendance decision unchanged. Access to credit also enabled households to reduce the impact of permanent shocks (such as parental death) on current consumption, including schooling investment. The response of these decisions to various shocks was proposed by Jacoby and Skoufias (1997), as a test of the completeness of credit markets.

\section{Labour market rigidities and schooling attendance}

Even if credit markets are complete, transitory shocks may prompt a change in schooling attendance in the presence of labour market rigidities. ${ }^{6}$ To illustrate, suppose that a child's parents (and possibly other adult family members) are involved in productive activities in the home (e.g., a family business or farm), and that the supply of labour in the outside market is perfectly elastic at an equilibrium wage, $w$. For simplicity, we considered the case of a household with one child, though our reasoning generalized to multiple children. ${ }^{7}$ A child will remain in school if the discounted future benefits of additional schooling (net of attendance costs) exceed the market wage, $w$ (adjusted for the child's productivity relative to an adult). In this situation, the family will hire outside labour as a replacement for family labour when an illness or mortality shock reduces family labour supply, no matter how much labour is required. The household will suffer a short-term loss of income; however, as long as the household can smooth consumption by borrowing, the child's school attendance status will be unchanged.

Next we considered the case in which there are labour market rigidities, such that the cost of hiring outside workers was higher than the shadow price of household labour. This may be the case because of transaction or monitoring costs associated with hired labour, for example. Letting $\tau$ represent the additional cost per unit of hired labour relative to family labour, then, for large enough $\tau$, it is possible that the cost of employing an outsider is higher than the opportunity cost of having the child leave school and work herself. ${ }^{8}$ The consequent decision to rely on the child's labour could thus be optimal, even if the household had full access to credit. If the household were credit constrained, the fall in income would also cause a drop in consumption, making dropout even more likely. ${ }^{9}$

\section{Distinguishing between labour and credit market rigidities}

We have described how, in the presence of labour market rigidities, shocks that affect household labour supply could cause children to drop out of school, even if there are no credit constraints. It would appear to be very difficult to distinguish whether labour or credit

\footnotetext{
${ }^{6}$ A full proof of this result was given in Glick et al. (2011).

${ }^{7}$ See Sawada (2003) for an exposition of the multiple-child case.

${ }^{8}$ Outside labour here includes anyone not normally involved in the household's income generating activities. Thus we implicitly included in the 'cost of hiring an outsider' the social, logistic or other costs of obtaining informal help, if these were available. This could also include the costs associated with obtaining help from the community or extended family members in a mutual insurance framework, such as reciprocal obligations to be repaid later, or shame in asking for help.

${ }^{9}$ This occurs because, without access to credit, the present marginal utility of consumption rises relative to the future marginal utility, making additional income today more attractive than the returns from an educational investment that will only be realized in the distant future.
} 
market imperfections are responsible for a link between labour-related shocks and school dropout, since these shocks typically affect both income and labour supply. However, there is a way to partially identify the two channels, under the assumption that there is imperfect substitutability by gender in household tasks.

This assumption is highly plausible in the case of Madagascar, as our data indicated that there are large gender differences in time spent in household productive activities. This is illustrated in Figure 1, which shows the average hours of work per week spent on farming (Panel a) and household chores (Panel b) for males and females, disaggregated by school attendance. Males spent slightly more time on farm work than women or girls, and significantly less on household chores. In other words, internal household labour markets in Madagascar tend to be at least partially segmented by gender. Furthermore, we saw that boys in school did less farm work than boys out of school, but about the same amount of housework. On the other hand, girls not in school spent significantly more time on housework than girls of the same age who attended school. This pattern is evidence of gender specialization in tasks, and suggested that girls would be more likely to substitute for the labour of their mother (in housework) if they left school, while boys would be more likely to substitute for their fathers (in farm work).

It is easy to see how this can lead to differential impacts by gender of paternal and maternal health or mortality shocks on the household's demand for children's labour. As discussed above, there must be labour market rigidities - in the sense of costs to hiring outside labour - in order for a transitory labour supply shock to influence school attendance in the presence of well-functioning credit markets. Allowing for the development of taskspecific human capital along gender lines means that parental labour supply shocks will differentially affect girls and boys. Consider the extreme case where there is no substitutability at all between male and female labour, and no possibility of hiring outside labour. If a father fell ill, the only source of substitute labour would be from boys, so the likelihood of dropout would rise for boys, but not for girls. ${ }^{10}$ This would be the case, even if there were no credit constraints.

We modelled the more general case of non-zero but imperfect substitutability across gender by assuming only that some additional cost is attached to boys' labour in tasks for which females have more skills and experience, and to girls' labour in tasks for which males have more skills and experience (analogous to the additional $\operatorname{cost} \tau$ of hiring outside labour). Importantly for our test between labour and credit market rigidities, we saw differential impacts by gender of parental labour shocks only if there were also labour market imperfections that precluded the family from hiring outside labour at a wage below the marginal benefit of schooling (since this is what, generally speaking, requires the family to rely on the labour of younger family members to substitute for reduced parental labour). In contrast, differential gender responses were not expected if only credit market imperfections were at work.

Our prediction of differential responses to shocks for boys and girls meant we could, to some extent, distinguish empirically between labour market and credit market rigidities, under the plausibly maintained assumption that there is imperfect substitutability of household labour by gender. Table 1 summarizes the predicted effects for the four different

\footnotetext{
${ }^{10} \mathrm{It}$ is, of course, possible that other idle family members or friends would provide assistance in the aftermath of a shock, diminishing the burden on the children to assist. However, this would tend to strengthen rather than weaken our conclusion, if we nevertheless observed differential dropout by gender.
} 
cases. In the case of perfect credit markets and no labour market rigidities, the marginal benefit of schooling was unchanged for boys and girls following a shock, so school attendance was affected for either sex (Case 1). If there were labour market rigidities but no credit constraints, shocks to the mother's labour supply would a greater effect on girls' school attendance, while shocks to the father's labour supply would more strongly affect boys. Nonlabour-related shocks would have no effect on enrolment (Case 2). In the presence of credit constraints and no labour market rigidities, shocks would affect both boys and girls equally (Cases 3 and 4). When both credit and labour markets were imperfect (Case 4), all shocks should have had an effect on attendance, and the effect should be greater on children of the same sex as the incapacitated parent. ${ }^{11}$ We tested for these cases in Section VI by interacting the gender of the child with mother's and father's illness and mortality shocks. Evidence of gender differences in response to shocks affecting labour of the mother or the father would support the hypothesis that labour market rigidities play a role in causing children to drop out of school in response to a shock.

\section{Econometric framework}

We employed a discrete hazard model to capture enrolment and drop-out decisions as a function of time-varying negative and positive shocks. Dropping out was defined as permanent exit from school. The models were estimated using conditional maximum likelihood, as described in Chamberlain (1984). This amounted to estimating a logit model of the probability of dropping out in a given period conditional on being enroled at the start of the period - that is, a discrete-time hazard model.

For child $i$ in household $h$, we specified the probability of dropping out of school as a logit function:

$$
\operatorname{Pr}\left(S_{t}=0 \mid S_{t-1}=1\right)=\Lambda\left[\alpha+X_{i h t} \beta+Z_{h t} \gamma+\Omega_{h t} \delta+\lambda_{a}^{\prime} \theta+v_{g}^{\prime} \pi+\eta_{i h t}\right]
$$

where $S_{t}$ was a state variable taking the value 1 if the child attended school in year $t$, and zero otherwise, and $\Lambda(z) \equiv \frac{\exp (z)}{1+\exp (z)}$. The enrolment model took the same form, but the values for $S_{t}$ were reversed. The regressors were individual child and household characteristics, $X_{i h}$, community characteristics, $Z_{h}$ and a vector of shocks hitting the household in period $t, \Omega_{h t .}{ }^{12}$ We included current as well as lagged values of the shocks (in the prior two years), to capture lags in adjustment or cumulative impacts, as well as to deal with possible recall errors in the precise year of specific events (both shocks and school dropout/entry decisions). ${ }^{13}$ We also included controls for child age, $\lambda_{a}$, and years at risk, $\nu_{g}$. By specifying dummy variables for age and years at risk, we allowed the baseline hazard to take a nonlinear form.

\footnotetext{
${ }^{11}$ It could be argued that rather than reflecting labour market imperfections, Cases 2 and 4 could represent differential income effects of the shock; indeed, a number of studies indicated higher income elasticities for girls' education (Glick, 2008). However, in that case, the difference between boys and girls would be the same for mother's and father's shocks. In contrast, our model predicted that the attendance responses would differ based on the gender of the afflicted parent.

${ }^{12}$ This specification followed directly from a standard exposition of the schooling attendance model outlined in the previous section. For details, see Glick et al. (2011).

${ }^{13}$ We also experimented with one-year leads and lags; the results were not substantially different.
} 
We specified the model as a panel logit with child-specific random effects to control for unobservable time-invariant individual heterogeneity. ${ }^{14}$ In the dropout model, each observation was one child-year for a child attending school between 1995 and 2004. For example, if a certain child attended school for five years during this period, the sample would include five observations for that child. Including child random effects linked these observations over time by a common heterogeneity component. In the enrolment model, each observation was one child-year for each year the child was 'at risk' of enrolling, starting at age 6 and ending when the child enrolled.

The explanatory variables of primary interest were the contemporaneous and lagged indicators of shocks reported by the household, $\Omega_{h t}$. We included shocks relating to the health of the mother and father (death and illness), prolonged unemployment of the household head, income shocks (year or season of significantly lower or higher than normal business income or crop loss) and asset shocks (loss of livestock or land).

The vector of child and household characteristics, $X_{i h}$, included child gender, a household wealth index constructed from various household assets using factor analysis as described by Sahn and Stifel (2003), and mother's and father's years of education, which captured parental tastes for schooling, income effects, and effects related to human capital accumulation (e.g., better educated parents may be better able to assist their children with schoolwork). In additional specifications, we also included the number of younger and older siblings by sex. The evidence regarding birth order seemed quite mixed, and by all indications was simply an empirical question that was determined by a range of potentially conflicting forces. ${ }^{15}$ We were also cognizant that the number of siblings was, in part, a function of household preferences for the quality and quantity of children, and hence, potentially endogenous to our schooling outcomes. Nonetheless, the question of whether the presence of younger siblings contributes to earlier school withdrawal (and conversely for older siblings) and how these effects differ by gender, provided interesting insights in terms of these relationships even if we could not draw definitive causal inferences.

We included in $Z_{h}$ a number of community and school characteristics. The community characteristics included a dummy for being in an urban community, the distance to the nearest school, whether piped water and electricity are available to at least some residents, and the presence of a lower and/or upper secondary school in the community. The school characteristics were based on the nearest primary school in the cluster: the average years of experience of the teachers, the proportion of classrooms with blackboards, indicators for whether the school was private, or part-time, and whether the school participated in the

\footnotetext{
${ }^{14}$ We also tried estimating a simple logit specification (with no random effects), a household fixed effects specification, and a model with household random effects. The results were qualitatively similar and are available from the authors on request. It was not possible to estimate a child fixed effects model, given the size of the data set.

${ }^{15}$ In favor of older children, one widely held explanation is that older children get a greater share of parental time (for example, Price (2008)). Hotz and Pantano (2013) also offered a series of explanations, including: 'differential discipline', i.e., that older children are treated more harshly than their younger siblings to serve as a deterrent; the theory of fertility stoppage, whereby parents with a difficult child will decide that they do not want more children, thus leading to the last born having worse outcomes; and the fact that later born children are more likely to experience a dissolution of the parental relationship, which could adversely affect their education. Conversely, older children may command higher wages and be more likely to enter the labour market. Younger children have older siblings who may assist with their learning. Finally, younger children, by definition, have older parents, who are more likely to have more secure financial situation and thereby be able to invest in their education.
} 
Secaline nutrition program in year $t$ (derived using information on date of initiation). Secaline provides school-based iron and folate supplementation, deworming and other school-based nutrition related activities, and was created in part to boost primary school enrolment. Given the non-experimental nature of the data, we were not able to control for potential endogeneity of placement of either the school or Secaline variables. That is, these variables may be correlated with the errors of the equations, if there were unobserved factors affecting both program placement and the schooling outcomes, leading to bias in the estimates. ${ }^{16}$

\section{Data}

The data came from the Etude sur la Progression Scolaire et la Performance Academique en Madagascar (EPSPAM), a household- and school-level survey conducted in 2004-2005, covering 73 rural and urban communities in Madagascar. The survey consisted of 2,100 households, for each of which detailed data were collected on the characteristics of household members, including educational attainment, health and employment, as well as householdlevel data on housing, assets and other factors.

Although the survey covered all the regions in Madagascar, it was not strictly nationally representative of all children. The reason was that the sample design involved returning to 48 communities from a larger education study - the Programme d'Analyse des Systemes Educatifs de la CONFEMEN (PASEC), which was conducted in 1998 in 120 clusters, defined by the catchment areas of primary schools in which scholastic aptitude tests took place. The original PASEC communities themselves were randomly selected from schools with at least 20 students in both the second and fifth grades. Given that schools are typically small in rural areas, the rural PASEC clusters thus tended to be larger-than-average communities. To partially address this issue, the 2004 survey supplemented the 48 PASEC clusters with an additional 12 clusters, randomly selected from all rural communities with small primary schools (after stratifying by province). ${ }^{17}$

In each of the original and new clusters, a complete enumeration was done of all children in the cohort's age range, and an equal number of students were selected who were not in the original PASEC sample. This was done to be sure to not exclude those who never attended school or enrolled very late. Thus, our final sample includes cohort members who would not have been selected by the original school-based survey, either because they lived in a very remote and small village, or because they did not attend school or delayed their enrolment.

In addition to the household-level data, the survey collected community- and schoollevel data on the nature and characteristics of existing infrastructure. In total, 140 schools were interviewed in the 73 clusters (i.e., communities) where the survey was conducted. Information was gathered on the experience and credentials of the principal and other management of the school, as well as the number of teachers, their qualifications and pedagogical practices, and building and classroom conditions. In the analysis that follows, we used information on the nearest primary school for all children in a given community.

\footnotetext{
${ }^{16}$ A paper by Glick et al. (2014) tested the hypothesis of endogenous program placement of Secaline with the same data set and did not find any sufficiently strong predictors among the commune-level variables. We also tried estimating both models, excluding the Secaline variable. We found that the exclusion did not substantially change the values or reduce the significance of the shock coefficients.

${ }^{17}$ The list of communities was taken from the Ministry of Education's database. 'Small' was defined as a school having fewer students than the national median of about 140 .
} 
The survey questionnaire carefully collected information on shocks using retrospective recall. The respondent was asked if each parent was living and, if not, the year of death. Each household member was asked about any illnesses, suffered in the previous 10 years (1995-2004) that had lasted more than a month and significantly impacted their ability to conduct normal activities. ${ }^{18}$ Although the problem with self-reported illness is well documented, the focus on functional implications mitigates to some extent the somewhat arbitrary nature of self-reports. Respondents were asked to report spells of unemployment lasting at least one month, including the date of job loss and its duration. The initial year of the unemployment shock was used for spells lasting more than one year. Questions were also asked about unanticipated losses of crops, livestock and land, and about years in which nonfarm revenues were well below or well above average.

We restricted our sample for the dropout model to children aged between 10 and 17 in 2004 and who were in school at age 10. Each of these children entered as one observation for each year over the 10-year reference period that they were 10 or older and in school, so that the sample for the dropout model contained a total of 28,264 child-year observations. The dependent variable took the value zero for each year the child stayed in school, and one in the year they dropped out. ${ }^{19}$ Even though late entry is common in Madagascar, almost all children who eventually attend school have enrolled by age 10, so this restriction minimized the risk of censoring the date of entry for some students. Similarly, $94 \%$ of the children in our sample had completed or dropped out of school by age 17. Although we could have extended the age range beyond 17, many children leave home after age 18, which could introduce sample censoring that would likely not be random. Overall, our sample for the dropout model comprised 4,109 children.

For the enrolment model, we modelled the time to school entry for school-age children. A child contributed an observation for each year during the period 1995-2004, during which they were 6 or older and were not enrolled in school the year before. The dependent variable took the value zero for each year the child was of school age and did not enrol that year, and one if the child did enrol. The sample for the enrolment model contained 3,511 children and 8,385 child-year observations.

Unfortunately, we did not have data on attendance within the school year, and therefore could not model how attendance responded to shocks (as done, for example, in Jacoby and Skoufias (1997)). We could only measure the effect of shocks on a child's permanent decision to leave school. It should be kept in mind that for this reason our estimates most likely understate the true effect of shocks on school attendance, since we were not capturing temporary withdrawals. At the same time, however, it was not clear at what point partial non-attendance begins to significantly affect education outcomes. Permanent dropout is therefore a conservative measure of the lasting effect of shocks on children's human capital accumulation.

\footnotetext{
${ }^{18}$ A concern with recall data is that more recent events are likely to be better remembered, leading to underreporting of earlier shocks. This is less likely to be the case for severe illness and death than for economic events. However, the frequency of reported shocks did not change substantially over the 10-year recall period, except for asset shocks. As mentioned above, the risk that dates could be misreported was controlled for by including leads and lags of the shocks in our model.

${ }^{19}$ For those children who did not drop out over this period, the dependent variable was zero for every child-year observation.
} 
Table 2 presents summary statistics for the variables of interest. Almost $13 \%$ of children in the sample had dropped out of school; this is the average of the low share of dropouts for younger children (just 1\% for 10-year-olds) and much higher rates for older children (39\% for 17-year-olds). Among those households with children aged 5 to 25 in 2004, the incidence of parental death during the previous 10 years was $2.0 \%$ for mothers and $4.3 \%$ for fathers; the incidence of serious illness among parents was also fairly uncommon, which is not unexpected since the measure only captured debilitating illnesses. The variable 'income shock' took the value 1 if the household experienced lower-than-expected crop or business income for the year; this was by far the most frequent shock reported. 'Asset shock', which took the value 1 if the household lost livestock or land during the period, was less frequent. Over the 10-year reference period, $35.4 \%$ of children in the dropout sample attended a school with the Secaline program. The dates of introduction (and, in some cases, removal) of this program varied across children, however. Figure 2 shows the initial enrolment and dropout rates by age for the children in the sample. Almost all children enrolled in school between six and eight years of age, with nearly half enrolling as six-year-olds. Only around 5\% of children began school after age eight. As expected, the distribution of dropouts was much less concentrated. The modal age of dropout was at 13.5 for boys and 13 for girls. Only $1.6 \%$ of children dropped out after age 18. Many of these late dropouts started school at a later age or repeated grades.

\section{Results}

The results of the hazard model are presented in Table 3 for dropout and school entry. We estimated a simple logit model, as well as household-level and child-level random effects models. Since the coefficient estimates from these three specifications were very similar, and had roughly the same levels of statistical significance, we present only the results for the child-level random effects model. ${ }^{20}$

\section{Impacts of health and economic shocks}

The probability of dropout was impacted by all of the health shocks included in the model, as well as some economic shocks. The death of a child's mother or father significantly raised the probability of the child dropping out in the following year. Father's death also had a lagged effect, with a magnitude of around one half the contemporaneous effect. The impacts of paternal and maternal death on dropout were not significantly different. The effect of father's and mother's illness on dropout were also strongly significant and of similar magnitude to the death shocks.

Unemployment and asset shocks both had a lagged positive effect on the probability of dropout. However, income shocks (defined as a bad harvest or an unexpected decline in household revenue) did not have any impact on school attendance. The lack of significance of the income shock variable may have been due to the subjective nature of the questiondefining a bad revenue year relative to normal is more subjective than, say, defining a debilitating illness. It was also possible, however, that households made efforts to compensate for temporary income shocks and were initially reluctant to pull children out of school in the face of short-term adversity. In contrast, loss of assets may have had a more

\footnotetext{
${ }^{20}$ The other model results are available from the authors on request.
} 
serious and long-term effect on household income, and consequently a greater impact on schooling. ${ }^{21}$

We found little impact of shocks on the enrolment decision. The exception was father's illness, which appeared to induce children to enrol in school earlier. At first glance, this result (essentially the opposite of the corresponding result for dropout) seemed counterintuitive. Note, however, that very young children were unlikely to be effective substitutes for an adult worker who fell ill. On the contrary, they were more likely to be a net burden on others in the household, in terms of care and supervision. A sick father might also require care and attention from the mother or others in the household, in which case parents would be induced to send their young children to school in order to have more time to care for the invalid.

We present the marginal effects of the shocks (or, more precisely, changes in probabilities) in Table 4, in order to convey the economic significance of the results. For the dropout model, we present the marginal effects for children aged 13 to 16 , while for the enrolment model, the marginal effects are presented for children aged six to eight. The marginal effects of the shocks were calculated holding other covariates constant at their sample means. The death of a 15-year-old child's mother raised the probability of her dropping out of school in the next year by 10.4 percentage points. Similarly, the death of a 15 -year-old's father raised the probability of dropout by 13.1 percentage points in the subsequent year. But that was not the entire effect, given the statistically significant coefficient on lagged parental death in the hazard model. The likelihood of dropout in the second and third years following the shock rose by 6.7 percentage points in response to a father's death, and by 3.7 percentage points in response to a mother's death. Illness among parents also had a large impact on the likelihood of dropout. Among 15-year-olds, for example, a child was 13.7 percentage points more likely to drop out if her father had a prolonged illness that interfered with work and other normal activities. The comparable number for the mother was 14.8 percentage points (although this was not significant).

As discussed previously, the only significant shock in the enrolment model was illness of the father. For a seven-year-old, such a shock raised the conditional probability of enrolment by 19 percentage points. Following the discussion above, this large effect may could be explained in part by the mother and others who are normally engaged in child care finding themselves with significantly greater demands on their time when there is a sick spouse also needing care. Sending a young child to school, therefore, becomes a way to reduce the overall care burden in the household.

\section{Community and school characteristics}

Among community characteristics, the presence in the nearest primary school of the health and nutrition program Secaline (which, as noted, was time-indexed using information on the year of its introduction) had a significant and negative effect on the probability of dropping out of school and led to earlier school entry (Table 3). Presumably, parents responded to the additional incentive of access to a free health and nutrition program at the school. Despite the statistically significant parameters, the marginal effects suggested that the size of Secaline's

\footnotetext{
${ }^{21}$ It is interesting to note that it was the lagged rather than contemporaneous asset shocks that were significantly associated with dropout in time $t$. While this could simply reflect imprecisions in the timing of events as discussed earlier, it could also suggest that households initially attempt to avoid withdrawing a child from school (or before completing a grade) when a loss of assets occurs.
} 
effect on the dropout decision was not large. For example, having Secaline in a child's school reduced her probability of dropout by a cumulative eight percentage points over the three years from age 14 to age 16 .

The impact on school enrolments appeared to be more substantial. For example, among six-year-olds, the presence of Secaline increased the probability of school enrolment by 6.2 percentage points. The program thus seemed to act as a strong incentive for school entry. One possible explanation for the smaller effect of Secaline on dropout is that children dropping out are doing so for significant reasons (such as negative shocks or low scholastic ability), which might outweigh the benefits of the program in their decision process. In interpreting these estimates, however, it is important to keep in mind the potential endogeneity of the placement and timing of this program.

We also examined the impact of other community covariates, including the presence of a lower and/or upper secondary school in the community. This also appeared to encourage earlier enrolment and discourage dropout. Again, focusing on the impact on 15-year-olds, the presence of a secondary school reduced the probability of dropout by 4.1 percentage points, and had a similar impact of the probability of enrolment among children between six and eight years of age. These results were plausible in that having an easily accessible secondary school would encourage children to continue their schooling beyond primary level (Appleton et al., 1996) and thereby increase the expected duration of schooling at the time of enrolment. Here, too, unmeasured community-level heterogeneity may influence both the presence of the characteristic, as well the outcomes; hence, these results need to be interpreted with caution.

In a similar vein, we included a variable capturing whether or not there was a private school alternative in the cluster. The presence of such an institution was associated with both earlier school entry and later dropout, although the impact was somewhat smaller than the presence of a secondary school. Interpreted causally (though subject to similar caveats as just expressed for other community covariates), this points to the benefits of having more - and possibly better - school options. In combination, these community and policy factors (existence of a secondary school, private school alternative and Secaline) were associated with an increase of over 13 percentage points in the probability of school entry each year from age six, relative to the baseline probability of $38 \%$.

We also included two other control variables for the general level of infrastructure: whether or not the community had electricity and piped water. Neither variable was significant in any of the dropout or school entry models.

To capture the effect of school quality, our models included a range of characteristics of the closest primary school, including information on the experience and education of the principal and teacher, the proportion of classrooms with blackboards, whether the school had part-time classes, whether there were separate toilets for boys and girls, and an interaction of separate toilets with the gender of the student. By and large, these school variables were found to have little or no impact on school entry or dropout. This is somewhat surprising, but may reflect the fact that we included characteristics of the nearest primary school to the community (rather than that of each child, which could lead to problems of endogeneity). We did find large regional- and district-level effects on the probability of enrolment, but not on dropout. In particular, living in a rural area was associated with a higher probability of enrolling in school earlier, a somewhat unexpected finding. One plausible explanation is that 
women in rural areas are more likely to be working in agriculture, and thus unable to care for younger children during the day.

\section{Household characteristics}

We included a range of household characteristics in the models. As expected, both mother's and father's education were positively related to earlier enrolment and negatively related to dropout, in accordance with findings in the literature. The magnitude of the marginal effect was relatively large for the enrolment decision: each additional year of mother's education raised the probability of the child starting school by 1.5 percentage points among six-yearolds. So, for example, a child whose mother had completed primary school was more than 15 percentage points more likely to enter school at age six than if the mother had no education. This important effect contrasted with the dropout models, where the marginal effects of education were smaller. Over the three-year period from age 14 to 16 , a mother having completed primary school reduced the probability of her child dropping out by a modest 6.7 percentage points.

Like parental education, household assets were positively related to early enrolment and reduced the probability of dropping out. These effects were consistent with education being a normal good. Associations between schooling and wealth (or income) were also frequently interpreted as evidence of credit constraints, since such constraints were more likely to be binding on poorer households with fewer assets (Jacoby, 1994; Jacoby and Skoufias, 1997). We interacted assets with the shock variables to see if households with more assets were better able to cope with shocks and less likely to take their children out of school. None of these interactions were significant.

We also ran a set of models that included covariates for the number of older and younger siblings by gender, and report the coefficients in Table 5. We did so, being cognizant of the issues of parental preferences influencing the number of children and investments in their human capital. Thus, we advise caution in examining these results, as they cannot be interpreted causally. The results suggested that there are large and significant sibling effects. The presence of older brothers and sisters in the household was associated with a reduced probability of dropping out. This effect was approximately twice as large for older brothers than older sisters. In contrast, the presence of younger siblings increased the probability of dropping out. One plausible explanation for these results is that the presence of younger siblings increases the demand for childcare, for which older siblings may be suitable. In contrast, having more older siblings implies a greater overall supply of family (and child) labour for home production and family enterprises, reducing the need for a given youth to give up school or not be in school. The enrolment models told a similar story, with the presence of older siblings contributing to earlier school entry, while the opposite was the case for the presence of younger siblings.

\section{Individual characteristics}

The gender of the child did not appear to impact the age at enrolment, but the dropout model indicated that, conditional on having attended school at time $t$-1, girls were more likely to withdraw from school at time $t$. While the latter finding was consistent with evidence from many other developing countries of gender disparities in education in favor of boys, it was somewhat unexpected here, given that Madagascar generally does not display serious gender inequality in education. 
Finally, we explored several other nonlinearities, including interacting age with shocks in the dropout model, in order to see whether older children were more or less likely to drop out following a shock. We found no significant relationships at the $10 \%$ level.

\section{Credit or labour market imperfections?}

As discussed in Section III, it was possible with our data to (partially) distinguish credit and labour market constraints as competing explanations for dropout in response to negative shocks, by interacting illness or death shocks for each parent with the gender of the child. As noted, given imperfect substitutability across gender in productive activities - such that it is easier for girls to substitute for mothers and boys for fathers-we would expect, given imperfect markets for hired labour, to find a stronger response of girls' schooling to maternal shocks and a stronger response of boys' schooling to paternal shocks. In contrast, no such differences would be observed if credit constraints alone were responsible for the effect of shocks on schooling decisions.

To test this hypothesis, we re-estimated the models including interactions of the shock variables with the gender of the child. The results (presented in Table 6) indicated that for both mother's and father's illness and death events, there were no significant differences in the (positive) responses of boys' and girls' dropout to these shocks. This suggests that labour market rigidities are not a significant factor in conditioning responses to parental shocks, but that credit constraints are a factor (since the shocks induced dropout for both girls and boys). These results, in other words, were consistent with Case 3 in Table 1. The apparent lack of influence of labour market rigidities - which would have predicted differential effects by gender to maternal and paternal shocks - may reflect the role of informal support (from extended family or neighbors) in helping households manage labour shortages, hence avoiding monitoring or other costs associated with hired labour. The finding that, instead, school dropout may result from credit market failures has broader implications, since it suggests that school attainment in general may also be constrained by a lack of access to credit.

\section{Conclusion}

In this paper, we estimated hazard models for school enrolment and dropout in Madagascar, using an unusually rich data set with information on educational attainment and retrospective data on economic and health events experienced by households. We found that negative shocks do increase the probability of withdrawal from school: the hazard of dropout was positively and significantly related to parental death, illness and unemployment, and to asset shocks, including loss of livestock or land. Age at school entry appeared generally to be less affected by such events, likely reflecting the fact that young children have limited potential to contribute to household income or production to compensate for negative shocks to household resources, and possibly that the direct costs of schooling in the initial primary years are relatively small. On the other hand, we found that community and school characteristics, such as the presence of health and nutrition programs in school, the existence of private school alternatives and secondary schools in the community, had more significant impacts on the decision to enroll a child than on the decision to drop out. Among other factors, higher parental education and household wealth increased the duration of schooling. 
We also developed a straightforward test for distinguishing the relative importance of credit market and labour market imperfections as constraints on schooling, where labour market imperfections refers to difficulties households face in sourcing outside labour for family enterprises or home production. We found that the likelihoods of girls and boys dropping out of school in response to a given parent's illness or death shock were similar in size, suggesting that access to alternative sources of labour is not a binding constraint on households' schooling investments, rather that credit constraints are likely the major factor. The test should be regarded as suggestive. It did not directly show that credit constraints affected schooling, only that labour market imperfections did not seem to play a role. Furthermore, this should not be taken to imply that households necessarily hire labour to replace incapacitated adult family members; it may also reflect well-functioning informal insurance in the form of supplementary labour from extended family and friends. Both results - as well as the negative association of early school leaving and household wealthare consistent with the presence of binding credit constraints on the education investment decisions of households. The evidence suggested that informal arrangements do not adequately insure households against these constraints.

The results of this study contribute to existing evidence that households in developing countries use their children as a risk-coping mechanism, pulling them out of school in response to large negative idiosyncratic shocks. Early dropout can have permanent impacts on human capital and earnings capacity, potentially leading to an intergenerational poverty trap. Policies that assist households to smooth income in times of stress - or provide access to credit so households can make long-term investments in education-can help to prevent this outcome. 


\section{References}

Appleton, S., Hoddinott, J. and Knight, J. (1996). 'Primary education as an input into postprimary education: a neglected benefit', Oxford Bulletin of Economics and Statistics, Vol. 58, pp. 211-219.

Becker, G. (1965). 'A theory of the allocation of time', Economic Journal, Vol. 75, pp. 493517.

Beegle, K., Dehejia, R.H. and Gatti, R. (2006). 'Child labor and agricultural shocks', Journal of Development Economics, Vol. 81, pp. 80-96.

Beegle, K., De Weerdt, J. and Dercon, S. (2007). 'The Long Run Impact of Orphanhood', World Bank Policy Research Working Paper No. 4353, The World Bank, Washington, DC.

Brown, P. and Park, A. (2002). 'Education and poverty in rural China', Economics of Education Review, Vol. 21, pp. 523-541.

Burke, K. (2006). 'Orphans in Sub-Saharan Africa', Mimeo, Cortland State University of New York.

Case A., Paxson, C. and Abledinger, J. (2004). 'Orphans in Africa: parental death, poverty, and school enrollment', Demography, Vol. 41, pp. 483-508.

Chamberlain, G. (1984). 'Panel data' in Griliches, Z. and Intriligator, M. (eds.), Handbook of Econometrics, North Holland, Amsterdam, pp. 1247-1318.

Duryea, S., Lam, D. and Levison, D. (2007). 'Effects of economic shocks on children's employment and schooling in Brazil', Journal of Development Economics, Vol. 84, pp. $188-214$.

Ersado, L. (2005). 'Child labor and schooling decisions in urban and rural areas: comparative evidence from Nepal, Peru, and Zimbabwe', World Development, Vol. 33, pp. 455-480.

Fafchamps, M. (2003). Rural Poverty, Risk and Development, Edward Elgar, Cheltenham, UK.

Fuller, B. and Liang, X. (1999). 'Which girls stay in school? The influence of family economy, social demands, and ethnicity in South Africa' in Bledsoe, C. H., Casterline, J. B., Johnson-Kuhn, J. A. and Haaga, J. G. (eds.), Critical Perspectives on Schooling and Fertility in the Developing World, National Academy Press, Washington, DC.

Gertler, P., Martinez, S., Levine, D. and Bertozzi, S. (2003). 'Losing the Presence and Presents of Parents: How Parental Death Affects Children', Mimeo, October 2003.

Gertler, P. Levine, D.I. and Ames, M. (2004). 'Schooling and parental death', The Review of Economics and Statistics, Vol. 86, pp. 211-225.

Glick, P. (1999). 'Patterns of Employment and Earnings in Madagascar', ILO Working Paper 92, Cornell University, Ithaca, NY http://www.ilo.cornell.edu/images/wp92.pdf

Glick, P. (2008). 'What policies will reduce gender schooling gaps in developing countries: evidence and interpretation', World Development, Vol. 36, pp. 1623-1646.

Glick, P., Handy, C. and Sahn, D. (2014). 'Schooling, Marriage, and Childbearing in Madagascar', CFNPP Working Paper No. 241, Cornell Food and Nutrition Policy Program, Ithaca, NY.

Glick, P., Sahn, D. and Walker, T. (2011). 'Household Shocks and Education Investment in Madagascar', CFNPP Working Paper No. 240, Cornell Food and Nutrition Policy Program, Ithaca, NY.

Hoftijzer, M. and Paci, P. (2008). 'Making Work Pay in Madagascar: Employment, Growth and Poverty Reduction', The World Bank, Washington, DC.

Hotz, V.J. and Pantano, J. (2013). 'Strategic Parenting, Birth Order and School Performance', NBER Working Paper No. 19542, Cambridge, MA.

Jacoby, H.G. (1994). 'Borrowing constraints and progress through school: evidence from Peru', Review of Economics and Statistics, Vol. 76, pp. 151-160. 
Jacoby, H.G. and Skoufias, E. (1997). "Risk, financial markets and human capital in a developing country', Review of Economic Studies, Vol. 65, pp. 311-335.

Jensen, R. (2000). 'Agricultural volatility and investments in children', American Economic Review, Vol. 90, pp. 399-404.

Lloyd, C.B. and Blanc, A.K. (1996). 'Children's schooling in sub-Saharan Africa: The role of fathers, mothers, and others', Population and Development Review, Vol. 22, pp. 265-298.

Operario, D., Cluver, L. and Rees, H. (2008). 'Orphanhood and completion of compulsory school education among young people in South Africa: findings from a national representative survey', Journal Of Research On Adolescence, Vol. 18, pp. 173-186.

Price, J. (2008). 'Parent-child quality time: does birth order matter?' Journal of Human Resources, Vol. 43, pp. 240-265.

Sahn, D.E. and Stifel, D. (2003). 'Exploring alternative measures of welfare in the absence of expenditure data', Review of Income and Wealth, Vol. 49, pp. 463-489.

Sawada, Y. (2003). 'Income Risks, Gender and Human Capital Investment in a Developing Country', Mimeo, University of Tokyo.

Sawada, Y. and Lokshin, M. (1999). 'Household Schooling Decisions in Rural Pakistan', Policy Research Working Paper No. 2541, The World Bank, Washington, DC.

Suryadarma, D., Pakpahan, Y. M. and Suryahadi, A. (2009). 'The Effects of Parental Death and Chronic Poverty on Children's Education and Health: Evidence from Indonesia', SMERU Working Paper, Chronic Poverty Research Centre, Jakarta, Indonesia.

Townsend, R.M. (1994). "Risk and insurance in Village India', Econometrica, Vol. 62, pp. 539-591.

Udry, C. (1994). 'Risk and insurance in a rural credit market: an empirical investigation in Northern Nigeria', Review of Economic Studies, Vol. 61, pp. 495-526.

World Bank (2008). 'The Challenge of Expanding Secondary Education and Training in Madagascar', Africa Region Human Development Department Working Paper No. 141, The World Bank, Washington, DC.

World Bank (2014). EdStats database, http://databank.worldbank.org/data/home.aspx 
TABLE 1

Effects of parental health or mortality shocks on schooling, by market constraint

\begin{tabular}{|c|c|c|c|}
\hline & & \multicolumn{2}{|c|}{ Credit market constraints } \\
\hline & & No & Yes \\
\hline \multirow{2}{*}{$\begin{array}{l}\text { Labour market } \\
\text { constraints }\end{array}$} & No & $\begin{array}{l}\text { 1. No effect of mother's or } \\
\text { father's shock on boys or } \\
\text { girls }\end{array}$ & $\begin{array}{l}\text { 3. Equal effects of mother's } \\
\text { and father's shocks on boys } \\
\text { and girls }\end{array}$ \\
\hline & Yes & $\begin{array}{l}\text { 2. Father's shock has a } \\
\text { greater effect on boys, } \\
\text { mother's shock a greater } \\
\text { effect on girls }\end{array}$ & $\begin{array}{l}\text { 4. Father's shock has a } \\
\text { greater effect on boys, } \\
\text { mother's shock a greater } \\
\text { effect on girls }\end{array}$ \\
\hline
\end{tabular}


TABLE 2

Summary Statistics

Sample for Enrolment Model

\begin{tabular}{|c|c|c|c|c|c|c|c|c|c|c|}
\hline Variable & $\mathrm{N}$ & Mean & SD & Min & Max & $\mathrm{N}$ & Mean & SD & Min & Max \\
\hline Dropped out / Enrolled & 3511 & 0.900 & 0.300 & 0 & 1 & 4109 & 0.128 & 0.334 & 0 & 1 \\
\hline \multicolumn{11}{|l|}{ Demographic variables } \\
\hline Male & 3511 & 0.493 & 0.500 & 0 & 1 & 4109 & 0.481 & 0.500 & 0 & 1 \\
\hline Mother years education & 3512 & 4.370 & 3.467 & 0 & 17 & 4110 & 4.654 & 3.522 & 0 & 17 \\
\hline Father years education & 3512 & 5.164 & 3.828 & $\begin{array}{l}0 \\
-\end{array}$ & 17 & 4110 & 5.412 & 3.864 & $\begin{array}{l}0 \\
-\end{array}$ & 17 \\
\hline Asset index & 3511 & -0.061 & 0.855 & 0.69 & 4.14 & 4109 & 0.046 & 0.948 & 0.69 & 4.18 \\
\hline Older brothers & 3511 & 1.204 & 1.197 & 0 & 8 & 3947 & 0.857 & 1.054 & 0 & 7 \\
\hline Older sisters & 3511 & 1.198 & 1.128 & 0 & 7 & 3947 & 0.747 & 0.915 & 0 & 5 \\
\hline Younger brothers & 3511 & 0.441 & 0.671 & 0 & 5 & 3947 & 0.921 & 0.959 & 0 & 7 \\
\hline Younger sisters & 3511 & 0.430 & 0.665 & 0 & 5 & 3947 & 0.935 & 0.976 & 0 & 7 \\
\hline \multicolumn{11}{|l|}{ Shock variables } \\
\hline Mother died & 3511 & 0.008 & 0.087 & 0 & 1 & 4109 & 0.020 & 0.142 & 0 & 1 \\
\hline Father died & 3511 & 0.016 & 0.125 & 0 & 1 & 4109 & 0.043 & 0.203 & 0 & 1 \\
\hline Mother sick & 3511 & 0.003 & 0.056 & 0 & 1 & 4109 & 0.012 & 0.107 & 0 & 1 \\
\hline Father sick & 3511 & 0.008 & 0.089 & 0 & 1 & 4109 & 0.021 & 0.143 & 0 & 1 \\
\hline Parent lost job & 3511 & 0.017 & 0.130 & 0 & 1 & 4110 & 0.052 & 0.223 & 0 & 1 \\
\hline Income shock & 3511 & 0.121 & 0.326 & 0 & 1 & 4109 & 0.282 & 0.450 & 0 & 1 \\
\hline Asset shock & 3511 & 0.027 & 0.162 & 0 & 1 & 4109 & 0.056 & 0.230 & 0 & 1 \\
\hline \multicolumn{11}{|l|}{ School characteristics } \\
\hline Principal years experience & 3511 & 11.010 & 8.986 & 0 & 36 & 4109 & 11.340 & 8.702 & 0 & 36 \\
\hline Principal years education & 3511 & 10.885 & 1.829 & 9 & 18 & 4109 & 10.881 & 1.878 & 9 & 18 \\
\hline Private school & 3511 & 0.180 & 0.378 & 0 & 1 & 4109 & 0.201 & 0.395 & 0 & 1 \\
\hline Part-time school & 3511 & 0.060 & 0.234 & 0 & 1 & 4109 & 0.048 & 0.210 & 0 & 1 \\
\hline Separate boys/girls toilets & 3511 & 0.165 & 0.371 & 0 & 1 & 4109 & 0.379 & 0.485 & 0 & 1 \\
\hline Teacher years experience & 3511 & 0.701 & 0.292 & 0 & 1 & 4109 & 0.727 & 0.265 & 0 & 1 \\
\hline Teacher years education & 3511 & 0.551 & 0.330 & 0 & 1 & 4109 & 0.535 & 0.335 & 0 & 1 \\
\hline $\begin{array}{l}\text { Proportion of classrooms } \\
\text { with blackboards }\end{array}$ & 3511 & 0.950 & 0.191 & 0 & 1 & 4109 & 0.954 & 0.174 & 0 & 1 \\
\hline \multicolumn{11}{|l|}{ Village characteristics } \\
\hline Urban & 3511 & 0.232 & 0.422 & 0 & 1 & 4109 & 0.261 & 0.439 & 0 & 1 \\
\hline Secaline & 3511 & 0.259 & 0.438 & 0 & 1 & 4109 & 0.354 & 0.478 & 0 & 1 \\
\hline Access to piped water & 3512 & 0.460 & 0.483 & 0 & 1 & 4110 & 0.500 & 0.481 & 0 & 1 \\
\hline Access to electricity & 3512 & 0.108 & 0.284 & 0 & 1 & 4110 & 0.123 & 0.297 & 0 & 1 \\
\hline Upper school in area & 3512 & 0.785 & 0.391 & 0 & 1 & 4110 & 0.820 & 0.358 & 0 & 1 \\
\hline \multicolumn{11}{|l|}{ Regions } \\
\hline Tana & 3512 & 0.225 & 0.417 & 0 & 1 & 4109 & 0.224 & 0.417 & 0 & 1 \\
\hline Fianar & 3512 & 0.219 & 0.413 & 0 & 1 & 4109 & 0.233 & 0.423 & 0 & 1 \\
\hline Toamasina & 3512 & 0.171 & 0.377 & 0 & 1 & 4109 & 0.167 & 0.373 & 0 & 1 \\
\hline Mahajanga & 3512 & 0.134 & 0.341 & 0 & 1 & 4109 & 0.131 & 0.337 & 0 & 1 \\
\hline Toliara & 3512 & 0.152 & 0.359 & 0 & 1 & 4109 & 0.152 & 0.359 & 0 & 1 \\
\hline Antsiranana & 3512 & 0.099 & 0.298 & 0 & 1 & 4109 & 0.094 & 0.292 & 0 & 1 \\
\hline
\end{tabular}

Notes: Dropout sample: Children aged 10-17 in 2004 who attended school in any of the ten years 1995 to 2004.

Enrollment sample: Children aged 6-12 who had not yet enrolled in any of the ten years 1995 to 2004.

Shock statistics are the proportion of children whose households experienced the shock at least once over the 10 -year reference period. 
TABLE 3

Model estimates

\begin{tabular}{|c|c|c|c|c|}
\hline \multirow[b]{2}{*}{ Variable } & \multicolumn{2}{|c|}{ Enrolment Model } & \multicolumn{2}{|c|}{ Dropout Model } \\
\hline & Coef. & Std. Err. & Coef. & Std. Err. \\
\hline Male & -0.049 & 0.057 & $-0.303 * *$ & 0.147 \\
\hline Mother's years education & $0.063 * * *$ & 0.011 & $-0.088 * * *$ & 0.029 \\
\hline Father's years education & $0.050 * * *$ & 0.009 & $-0.123 * * *$ & 0.031 \\
\hline Asset index & $0.198 * * *$ & 0.046 & $-0.410 * * *$ & 0.127 \\
\hline Secaline & $0.265 * * *$ & 0.075 & $-0.528 * * *$ & 0.156 \\
\hline Access to piped water & 0.041 & 0.063 & -0.165 & 0.142 \\
\hline Access to electricity & -0.053 & 0.128 & 0.572 & 0.356 \\
\hline Upper school in area & $0.175^{* *}$ & 0.079 & $-0.803 * * *$ & 0.213 \\
\hline Urban & $-0.195 * *$ & 0.091 & -0.196 & 0.21 \\
\hline Mother died at $\mathrm{t}$ & -0.078 & 0.448 & $1.287 * *$ & 0.514 \\
\hline Mother died at $\mathrm{t}-1$ or $\mathrm{t}-2$ & 0.093 & 0.314 & 0.484 & 0.600 \\
\hline Father died at $t$ & -0.083 & 0.305 & $1.519 * * *$ & 0.411 \\
\hline Father died at $\mathrm{t}-1$ or $\mathrm{t}-2$ & 0.080 & 0.225 & $0.802 * *$ & 0.407 \\
\hline Mother sick at $\mathrm{t}$ & 0.457 & 0.666 & $1.640^{* *}$ & 0.757 \\
\hline Father sick at t & $0.978 * *$ & 0.460 & $1.561 * * *$ & 0.542 \\
\hline Parent lost job at $\mathrm{t}$ & 0.191 & 0.296 & -0.116 & 0.558 \\
\hline Parent lost job at $\mathrm{t}-1$ or $\mathrm{t}-2$ & 0.194 & 0.246 & $0.671^{*}$ & 0.383 \\
\hline Income shock at $\mathrm{t}$ & 0.151 & 0.105 & -0.212 & 0.183 \\
\hline Income shock at $\mathrm{t}-1$ or $\mathrm{t}-2$ & -0.160 & 0.104 & 0.005 & 0.174 \\
\hline Asset shock at $t$ & 0.293 & 0.230 & 0.284 & 0.352 \\
\hline Asset shock at $\mathrm{t}-1$ or $\mathrm{t}-2$ & 0.291 & 0.186 & $0.962 * * *$ & 0.298 \\
\hline Principal years experience & 0.002 & 0.004 & 0.009 & 0.009 \\
\hline Principal years education & $-0.044 * *$ & 0.021 & 0.058 & 0.050 \\
\hline Private school & $0.234 * *$ & 0.091 & $-0.659 * * *$ & 0.237 \\
\hline Part-time school & -0.190 & 0.124 & $0.480 *$ & 0.263 \\
\hline Separate toilets & 0.164 & 0.103 & 0.073 & 0.197 \\
\hline Separate toilets $\times$ female & -0.005 & 0.138 & -0.102 & 0.239 \\
\hline Teacher's years experience & $-0.187^{*}$ & 0.113 & -0.439 & 0.274 \\
\hline Teacher's years education & -0.078 & 0.104 & -0.237 & 0.250 \\
\hline Proportion blackboards & 0.010 & 0.152 & $0.615^{*}$ & 0.372 \\
\hline Observations & \multicolumn{2}{|c|}{8,385} & \multicolumn{2}{|c|}{28,264} \\
\hline Groups & \multicolumn{2}{|c|}{3,511} & \multicolumn{2}{|c|}{4,109} \\
\hline
\end{tabular}

Notes: Individual-level random-effects logit models. Dependent variable: enrolled/dropped out during year.

Controls for village, age and year at risk included (not reported). Full results available from the authors upon request.

$* * *$ denotes significant at $1 \%, * *$ at $5 \%$ and $*$ at $10 \%$. 
TABLE 4

Contemporaneous marginal effects of shocks and characteristics

\begin{tabular}{|c|c|c|c|c|c|c|c|c|c|}
\hline \multirow[b]{3}{*}{ Variable } & \multirow{3}{*}{$\begin{array}{c}\text { All } \\
\text { ages }\end{array}$} & \multicolumn{4}{|c|}{ Enrolment Model } & \multicolumn{4}{|c|}{ Dropout Model } \\
\hline & & \multicolumn{3}{|c|}{ Age } & \multirow{2}{*}{$\begin{array}{c}\text { All } \\
\text { ages }\end{array}$} & \multicolumn{4}{|c|}{ Age } \\
\hline & & 6 & 7 & 8 & & 13 & 14 & 15 & 16 \\
\hline Mother died & -1.5 & -1.8 & -1.8 & -1.8 & $2.7^{*}$ & 5.6 & $7.7^{*}$ & $10.4^{*}$ & $12.6^{*}$ \\
\hline Father died & -1.6 & -1.9 & -1.9 & -1.9 & $3.5^{* *}$ & $7.2^{* *}$ & $9.8^{* *}$ & $13.1^{* *}$ & $15.8^{* *}$ \\
\hline Mother sick & 9.1 & 10.6 & 9.7 & 9.6 & 4.0 & 8.3 & 11.2 & 14.8 & 17.7 \\
\hline Father sick & $19.6^{* *}$ & $21.8^{* *}$ & $19.0^{* * *}$ & $18.6^{* * *}$ & $3.6^{*}$ & $7.6^{*}$ & $10.3^{*}$ & $13.7^{*}$ & $16.5^{* *}$ \\
\hline $\begin{array}{l}\text { Parent lost } \\
\text { job }\end{array}$ & 3.8 & 4.5 & 4.2 & 4.2 & -0.1 & -0.3 & -0.4 & -0.6 & -0.7 \\
\hline $\begin{array}{l}\text { Income } \\
\text { shock }\end{array}$ & 3.0 & 3.6 & 3.4 & 3.3 & -0.2 & -0.5 & -0.7 & -1.0 & -1.3 \\
\hline Asset shock & 5.8 & 6.9 & 6.4 & 6.3 & 0.4 & 0.8 & 1.1 & 1.6 & 2.0 \\
\hline $\begin{array}{l}\text { Mother's } \\
\text { education }\end{array}$ & $1.2^{* * *}$ & $1.5^{* * *}$ & $1.4^{* * *}$ & $1.4^{* * *}$ & $-0.1^{* * *}$ & $-0.2^{* * *}$ & $-0.3^{* * *}$ & $-0.4^{* * *}$ & $-0.6^{* * *}$ \\
\hline $\begin{array}{l}\text { Father's } \\
\text { education }\end{array}$ & $1.0^{* * *}$ & $1.2^{* * *}$ & $1.1^{* * *}$ & $1.1^{* * *}$ & $-0.2^{* * *}$ & $-0.3^{* * *}$ & $-0.4^{* * *}$ & $-0.6^{* * *}$ & $-0.8^{* * *}$ \\
\hline $\begin{array}{l}\text { Secaline } \\
\text { Unper }\end{array}$ & $5.2^{* * *}$ & $6.2^{* * *}$ & $5.9^{* * *}$ & $5.8^{* * *}$ & $-0.6^{* * *}$ & $-1.3^{* *}$ & $-1.9^{* *}$ & $-2.7^{* * *}$ & $-3.4^{* * *}$ \\
\hline school & $3.4^{* *}$ & $4.1^{* *}$ & $3.9^{* *}$ & $3.9^{* *}$ & $-1.0^{* * *}$ & $-2.0^{* * *}$ & $-2.8^{* * *}$ & $-4.1^{* * *}$ & $-5.2^{* * *}$ \\
\hline $\begin{array}{l}\text { Private } \\
\text { school }\end{array}$ & $4.6^{* *}$ & $5.5^{* *}$ & $5.3^{* * *}$ & $5.2^{* * *}$ & $-0.8^{* * * *}$ & $-1.6^{* *}$ & $-2.3^{* * *}$ & $-3.3^{* * *}$ & $-4.2^{* *}$ \\
\hline
\end{tabular}

Notes: The marginal effects are point estimates of the percentage point increase in the probability of enrollment/dropout (over the baseline) for children whose household suffered that shock in the current period. In calculating the marginal effects, we set all other regressors to their sample averages.

$* * *$ denotes significant at $1 \%, * *$ at $5 \%$ and $*$ at $10 \%$. 
TABLE 5

Coefficient estimates for sibling variables

\begin{tabular}{lcccc}
\hline \multirow{2}{*}{ Variable } & \multicolumn{2}{c}{ Enrolment model } & \multicolumn{2}{c}{ Dropout model } \\
Coef. & Std. Err. & Coef. & Std. Err. \\
\hline Older brothers & & & & \\
Older sisters & 0.042 & 0.026 & $-0.360^{* * *}$ & 0.092 \\
Younger brothers & $0.064^{* *}$ & 0.029 & $-0.182^{* *}$ & 0.092 \\
Younger sisters & $-0.114^{* *}$ & 0.049 & $0.199^{* * *}$ & 0.068 \\
& $-0.110^{* *}$ & 0.047 & $0.218^{* * *}$ & 0.066 \\
\hline \multirow{2}{*}{ Observations } & \multicolumn{2}{c}{28,095} \\
Groups & \multicolumn{2}{|c}{3,385} & \multicolumn{2}{c}{3,947} \\
\hline
\end{tabular}

Notes: Individual-level random-effects logit models. Dependent variables: enrolled and dropped out during year, respectively. Enrollment sample includes one observation for each child aged 6 or over, and not enrolled in the previous year, during the 10 years 1995 to 2004. Dropout sample includes all children enrolled in a given year, with one observation for each child enrolled in the 10 years 1995 to 2004. Models include controls for village, age and year at risk, as well as all variables in Table 3 (not shown). Full results available from the authors upon request.

$* * *$ denotes significant at $1 \%, * *$ at $5 \%$ and $*$ at $10 \%$. 
TABLE 6

Coefficient estimates for gender-shock interactions

\begin{tabular}{|c|c|c|c|c|}
\hline \multirow[b]{2}{*}{ Variable } & \multicolumn{2}{|c|}{ Enrolment Model } & \multicolumn{2}{|c|}{ Dropout Model } \\
\hline & Coef. & Std. Err. & Coef. & Std. Err. \\
\hline Mother died at $\mathrm{t}$ & 0.142 & 0.607 & $1.617 * * *$ & 0.598 \\
\hline interacted with female & -0.450 & 0.892 & -1.090 & 1.038 \\
\hline Mother died at $\mathrm{t}-1$ or $\mathrm{t}-2$ & 0.165 & 0.497 & 0.378 & 0.806 \\
\hline interacted with female & -0.114 & 0.640 & 0.072 & 1.142 \\
\hline Father died at $\mathrm{t}$ & 0.088 & 0.453 & $1.666^{* * *}$ & 0.598 \\
\hline interacted with female & -0.300 & 0.612 & -0.283 & 0.774 \\
\hline Father died at $\mathrm{t}-1$ or $\mathrm{t}-2$ & 0.018 & 0.340 & 0.708 & 0.581 \\
\hline interacted with female & 0.120 & 0.454 & 0.101 & 0.735 \\
\hline Mother sick at $\mathrm{t}$ & -16.910 & 2763.0 & 1.195 & 1.198 \\
\hline interacted with female & 18.440 & 2763.0 & 0.682 & 1.492 \\
\hline Father sick at $\mathrm{t}$ & $1.600 * * *$ & 0.612 & $1.957 * * *$ & 0.742 \\
\hline interacted with female & -1.403 & 0.918 & -0.816 & 1.053 \\
\hline Parent lost job at $\mathrm{t}$ & 0.385 & 0.371 & -0.101 & 0.776 \\
\hline interacted with female & -0.383 & 0.634 & -0.261 & 1.130 \\
\hline Parent lost job at $\mathrm{t}-1$ or $\mathrm{t}-2$ & 0.101 & 0.327 & -0.239 & 0.767 \\
\hline interacted with female & 0.125 & 0.498 & 1.307 & 0.869 \\
\hline Income shock at $\mathrm{t}$ & $0.249^{*}$ & 0.152 & -0.003 & 0.251 \\
\hline interacted with female & -0.204 & 0.210 & -0.407 & 0.360 \\
\hline Income shock at $\mathrm{t}-1$ or $\mathrm{t}-2$ & -0.163 & 0.146 & 0.233 & 0.242 \\
\hline interacted with female & 0.016 & 0.206 & -0.422 & 0.341 \\
\hline Asset shock at $\mathrm{t}$ & $0.601^{*}$ & 0.315 & -0.600 & 0.650 \\
\hline interacted with female & -0.644 & 0.460 & $1.439 *$ & 0.776 \\
\hline Asset shock at t- 1 or $\mathrm{t}-2$ & 0.435 & 0.285 & $0.897 * *$ & 0.394 \\
\hline interacted with female & -0.246 & 0.370 & 0.042 & 0.521 \\
\hline Observations & \multicolumn{2}{|c|}{8,385} & \multicolumn{2}{|c|}{28,102} \\
\hline Groups & \multicolumn{2}{|c|}{3,511} & \multicolumn{2}{|c|}{3,947} \\
\hline
\end{tabular}

Notes: Individual-level random-effects logit model. Dependent variable: dropped out during year.

Sample includes all children enrolled in a given year, with one observation for each child enrolled in the ten years 1995 to 2004 .

Includes controls for village, age and year at risk, and the school-specific variables listed in Table 3 (excluded here for parsimony).

$* * *$ denotes significant at $1 \%, * *$ at $5 \%$ and $*$ at $10 \%$. 
1a. Farm work

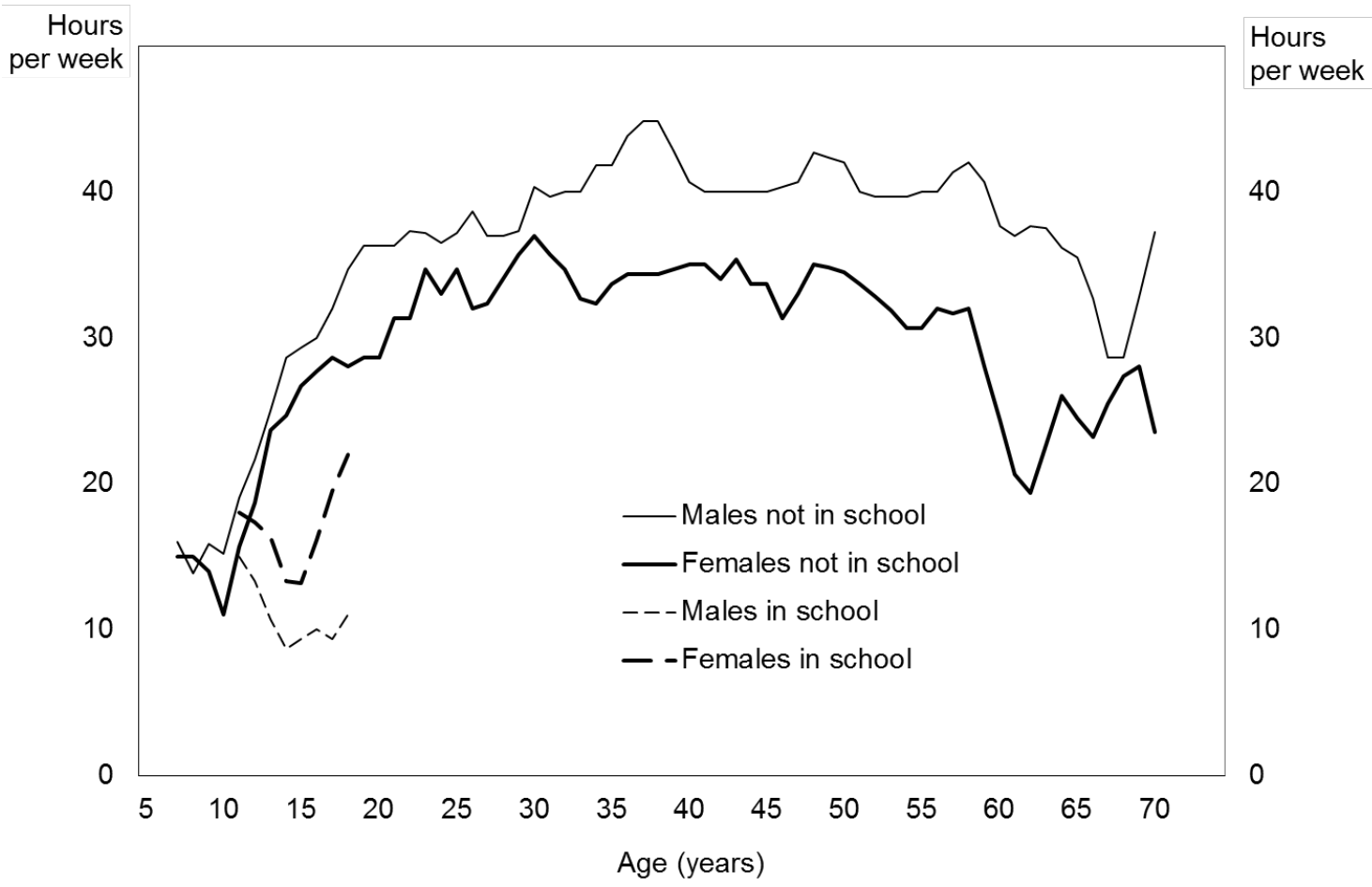

1b. House work

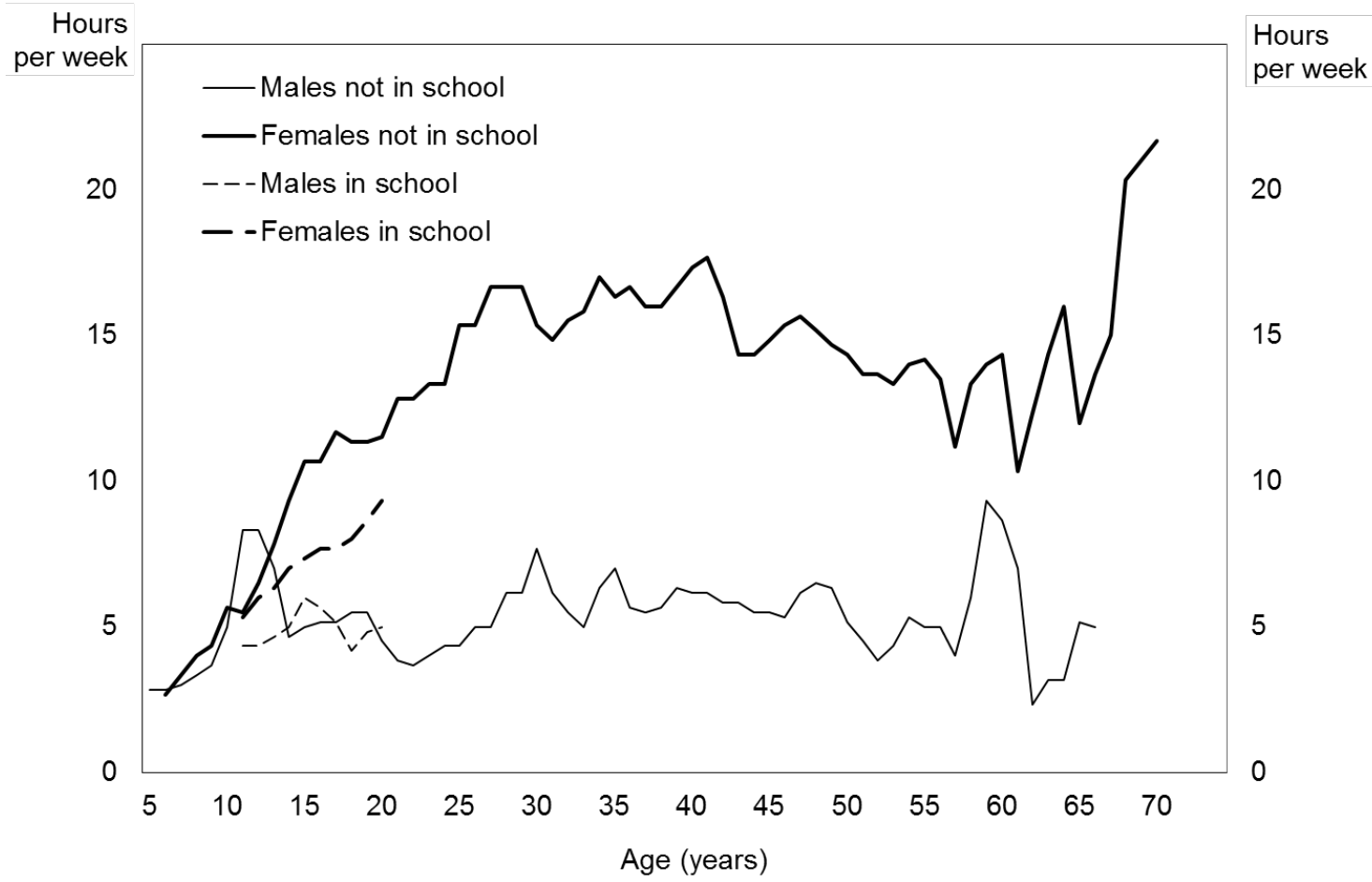

Figure 1. Time use by gender and school attendance status 
2a. Age enrolled in school

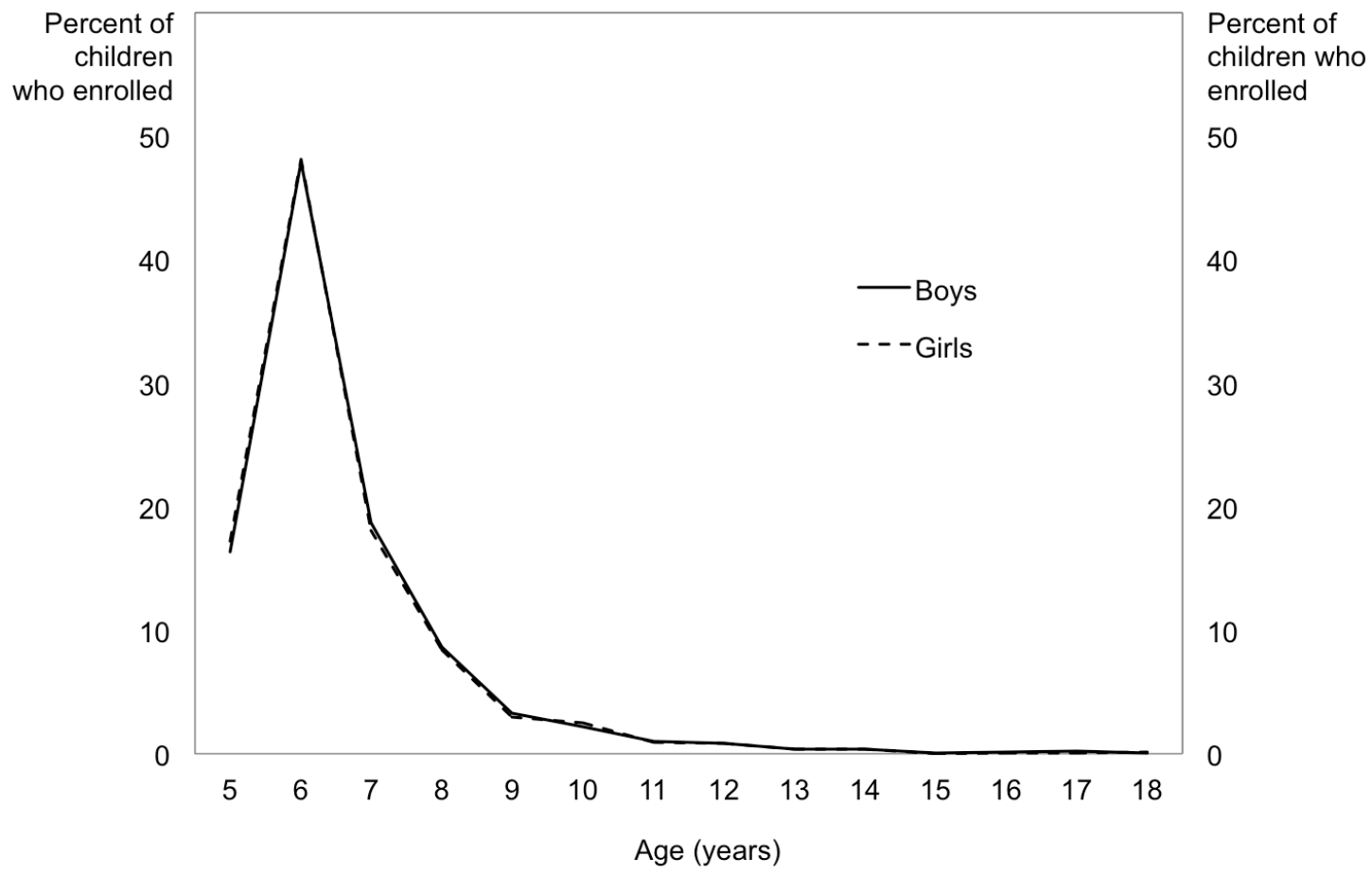

2b. Age left school

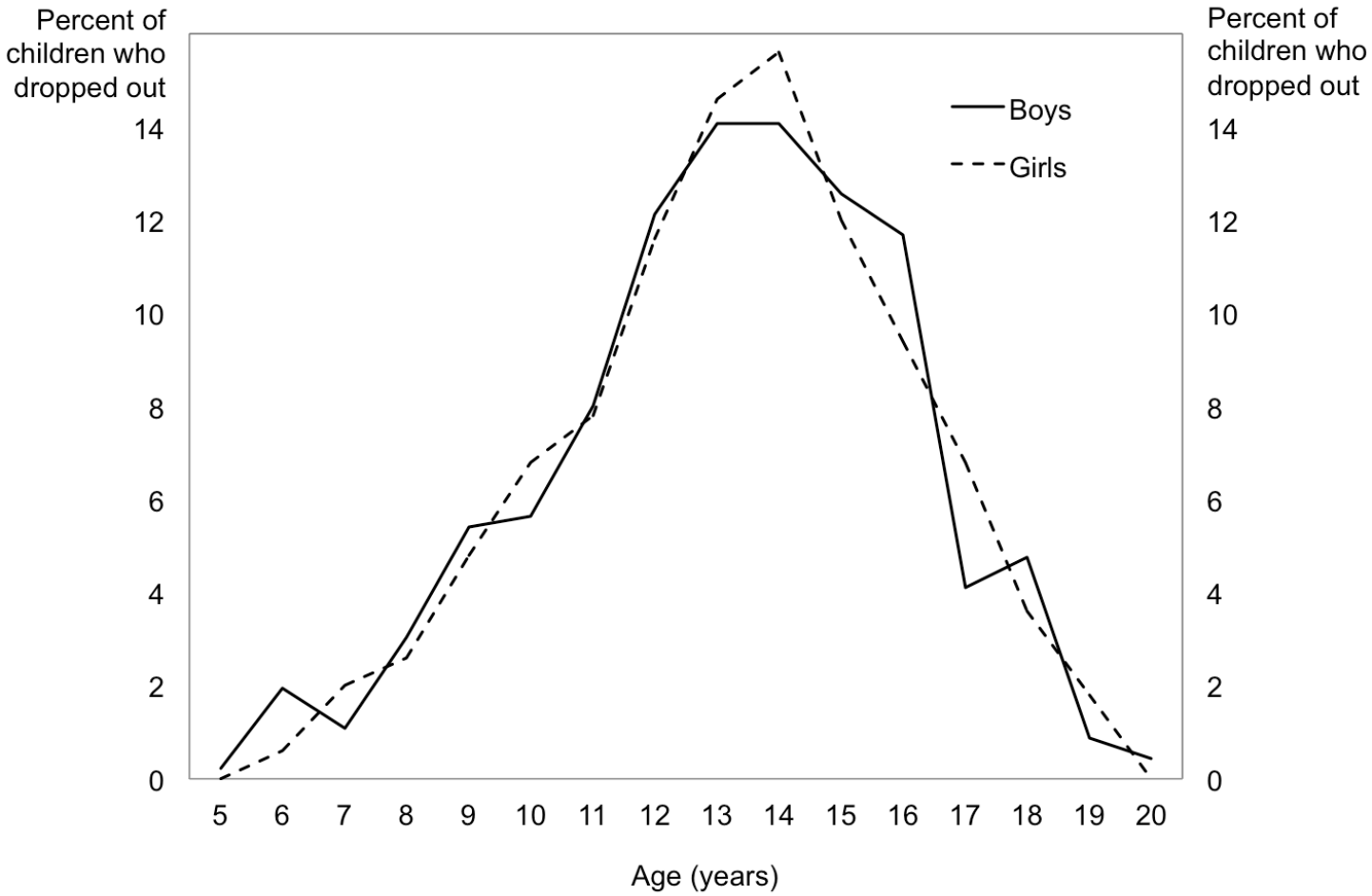

Figure 2. Conditional probabilities of school enrolment and dropout, by age 